\title{
Службы безопасности и парламентские комиссии для расследования в Германии: прозрачность или конфиденциальность
}

\author{
Себастьян фон Мюнхов *
}

\section{Введение}

«Хорошее управление» - это политическая концепция, с помощью которой государства в состоянии перехода и постконфликтные государства пытаются интегрироваться в международное сообщество, которое придерживается идеалов демократии и верховенства закона и делает ставку на волю народа. Одним из решающих факторов для реализации хорошего управления является вопрос о том, как сектор безопасности взаимодействует с государством и способствует общественному благу. В частности, сектор безопасности должен быть объектом гражданского наблюдения и контроля, должен принимать решения, которые понятны, и должен отвечать за несоответствующее поведение и незаконные действия.

Эта концепция привела к появлению распространенного во всем мире движения за реформы в секторе безопасности (РСБ). По мере формирования и реализации повестки дня РСБ в течение последнего десятилетия нарастало давление, направленное на улучшение интегрирования сектора безопасности в систему государства с целью ограничить использование сил безопасности в качестве репрессивного инструмента власти конкретного режима, клана или личности. Это наиболее важная задача, с которой сталкиваются страны, включающиеся в процесс РСБ, которые ориентируются на сближение с евро-атлантическим пространством безопасности, причем наиболее критическим элементом реформирования сектора безопасности является создание национальной концепции безопасности, которая соответствует современным стандартам прозрачности.

Доктор Себастьян фон Мюнхов работает лектором по вопросам исследований в сфере безопасности и по международному/европейскому праву в Европейском центре исследований по вопросам безопасности им. Джорджа К. Маршалла. Он изучал право в Свободном университете Берлина, в университете Лозанны и в университете имени Християна-Альбрехта в Киле. После получения магистерской степени по праву он сдал экзамен на адвоката в Берлине и стал доктором по международным отношениям в Венском Университете в области многосторонних ангажементов в постконфликтном установлении мира. Затем доктор фон Мюнхов работал в миссиях Организации по безопасности и сотрудничеству в Европе в Боснии и Герцеговине, а также и в Косове. Он служил в миссии Европейского союза по содействию полиции в Тиране. В Брюсселе начал работать в офисе Специального координатора Пакта стабильности для Юго-Восточной Европы, где он руководил несколькими инициативами, направленными на укрепление секторов внутренних дел и правосудия на Балканах. По возвращении в Германию доктор фон Мюнхов стал сотрудником правительства и проработал несколько лет в Федеральной канцелярии. 
В свете этого несколько государств Кавказа, Южной Европы и Ближнего Востока начали реализовывать реформы, направленные на укрепление парламентского контроля и государственного мониторинга за полицейскими службами, вооруженными силами и разведывательными органами. Есть много примеров, когда в прошлом секторы безопасности в этих и других регионах были причастны к серьезным нарушениям прав человека и вступали в заговор с целью поддерживать коррумпированные или тиранические режимы. Имея в виду это иногда трудное прошлое, становится еще даже более очевидным, насколько велика работа, которая необходима для реализации реформы, направленной на обеспечение прозрачности в секторе безопасности. Видимые признаки реализации хорошего управления в лучшем случае трудноразличимы как в сфере внутренней, так и внешней безопасности, что затрудняет их идентификацию. Однако, если парламентский контроль и внимательное наблюдение министерствами гражданского управления приводит к выявлению серьезных недостатков в аппарате власти государства - и в частности, в чувствительной сфере разведывательных служб, - и может дать разумные выводы без скатывания в традиционные поведенческие схемы, то это было бы хорошим признаком прогресса. Федеральная Республика Германия потратила десятки лет на реформирование своего сектора безопасности и может служить для других государств примером, которому стоить следовать.

В течение последних нескольких десятилетий Федеральная Республика Германия создала комплексную систему сдержек и балансов для обеспечения надзора за сектором безопасности. Некоторыми из сдержек и балансов, которые были интегрированы во многих слоях сектора безопасности для обеспечения достаточного надзора, являются:

- Четкое разделение сфер ответственности между федеральными и провинциальными службами

- Упор на разные аспекты надзора за сектором безопасности в форме парламентского контроля и мониторинга органами исполнительной власти

- Соответствующая судебная система наряду с такими институциями, как постоянная Группа парламентского контроля

- Расследование и опубликование в средствах массовой информации сведений о случаях несоответствующего поведения и незаконных действий.

Подобным образом и другие ориентированные на Запад страны создали разнообразные механизмы контроля и надзора за их секторами безопасности, хотя масштаб, средства интервенции и состав ответственных органов может варьировать. Чаще всего баланс между исполнительной и законодательной властью приводит к учреждению экспертных или парламентских институций, предназначенных для решения вопросов бюджета, законности действий и стратегического согласования разведывательных служб.

Уникальными для Германии являются ad hoc (по случаю) парламентские Комиссии по расследованию (ПКР) на федеральном уровне. В прошлом эти специальные комиссии фокусировались на проблемах безопасности и на том, как власти 
Германии с этими проблемами справляются. Естественно, возникали определенные трения между ветвями законодательной и исполнительной власти. Парламентская сторона привлекала внимание массовой публики при выяснении определенных обстоятельств и требовала, чтобы расследование было тщательным. Со своей стороны, службы безопасности иногда неохотно раскрывали чувствительную информацию. И как раз в этом состоит отличие от других моделей надзора и контроля. В отличие от множества других постоянных институций контроля и надзора, члены ПКР в Германии пользуются неограниченным доступом к секретным материалам, а их работа облегчается обязанностью свидетелей являться на слушания и возможностью публично осуждать любое несоответствующее поведение или незаконные действия со стороны служб безопасности и разведки. Интенсивные методы расследования, которыми пользуются во время расследования члены ПКР - и которые всегда являются балансом между необходимой конфиденциальностью и правом информировать публику, - как раз и делают немецкий подход интересным для тех государств, которые ищут способы, как лучше осуществлять контроль за своим сектором безопасности, в том числе и за разведывательными службами.

Обращаясь к конкретным случаям, я хочу обрисовать особенности комиссий по расследованию в Германии. Задача балансировать между конфиденциальностью и прозрачностью станет очевидной при рассмотрении правовых вопросов и при представлении действительных методов и практик, используемых правительством. Статья заканчивается изложением некоторых соображений относительно того, могут ли ПКР в Германии служить моделью для государств, находящихся в процессе перехода.

\section{Взгляд на предыдущие ПКР}

Рассматривая ситуацию в Германии за последние двадцать лет, можно заметить, что в каждом законодательном сроке был по крайней мере один инцидент, связанный с внешней политикой и безопасностью, который приводил к расследованию на федеральном уровне, длившемуся несколько лет и порождавшему эмоциональные обсуждения. ${ }^{1}$ Эти комиссии периодически становились объектом пристального внимания со стороны средств массовой информации, и некоторые из них вызвали существенный общественный резонанс, приведший к тому, что несколько министров и высших администраторов были наказаны или даже подали в отставку. Политические партии, вовлеченные в расследование, позиционировали

1 Этот подход контрастирует с расследованиями в федеральных землях Германии, которые обычно сфокусированы на использовании общественных фондов - обычно в спорных широкомасштабных строительных проектах. Смотри, к примеру, Штутгарт 21, «Рекомендательное решение и доклад Комиссии по транспорту, строительству и городскому развитию», BT-D принт 17/5172 (22 марта 2011); и «Оценочный доклад Парламентской комиссии для расследования: Зал филармонии Елбе, граждане свободного и ганзейского города Гамбурга», принт 19/8400 (21 января 2011), 5. 
себя согласно повторяющейся модели: тогда как оппозиция интерпретировала факты случая как скандальные, соответствующая правительственная коалиция, чьи действия были объектом расследования, старалась комментировать расследование как можно меньше или пыталась успокоить своих политических оппонентов.

Во время работы парламента двенадцатого созыва расследованию подверглась роль бывшего главы Департамента коммерческой координации в бывшей Восточной Германии Александра Шлак-Голодовского. ${ }^{2}$ Всего через год, во время работы собрания тринадцатого созыва с 1995 по 1998 год, Федеральная Разведывательная Служба (ФРС) была вынуждена оправдывать свои действия в связи с так называемым «плутониевым скандалом». ${ }^{3}$ Внешняя политика была в центре внимания в так называемом «визовом деле» во время работы парламента пятнадцатого созыва, ${ }^{4}$ а при следующем парламенте имело место возможно наиболее серьезное до сих пор парламентское расследование работы органов безопасности Германии. ПКР рассматривали и индивидуальные случаи, как например, случаи Халида Ел-Масри, Мохамеда Заммара и Мурата Курназа, временно задержанных в Соединенных Штатах в связи с борьбой с терроризмом, деятельность Германии в Багдаде во время Второй войны в Заливе и надзор и наблюдение за журналистами службами безопасности под предлогом защиты вооруженных сил и обеспечения безопасности операций. ${ }^{5}$ Во время работы парламента семнадцатого созыва Комитет по обороне выступил в качестве Комиссии парламентского расследования и поставил под вопрос законность немецкого воздушного удара против двух автоцистерн в

2 Смотри «Рекомендательное решение и дополнительный доклад Первой комиссии для расследования: Рассмотрение роли департамента «Коммерческой координации» и его главы Александра Шлак-Голодовского в руководстве СЕПГ, государственном контроле и экономике ГДР, и выводы о том, кому была выгодна или кому сейчас выгодна экономическая деятельность этого департамента», Бундестаг принт 12/8595 (2 ноября 1994), 39.

3 Смотри «Рекомендательное решение и доклад Первой комиссии для расследования: выводы комиссии об инциденте с мюнхенским плутонием и по вопросам, связанным с этим и другими инцидентами, с фокусом на ответственность федерального правительства и персонала федеральных ведомств» (КПР Плутониум) Бундестаг принт 13/10800 (28 май 2008), 45.

4 Смотри «Рекомендательное решение и доклад Второй комиссии для расследования: выводы о том, скомпрометировали ли или допустили угрозу безопасности Федеральной Республики Германия или других стран Шенгена члены федерального правительства или сотрудники федеральной власти с октября 1998 года, применяя иммиграционные законы при издании декретов, инструкций или иначе, и в частности, при выдаче виз в дипломатических миссиях Германии, в частности в Москве, Киеве, Тиране и Приштине» (КПР «Виза»), Бундестаг принт 15/5975 (2 сентября 2005), 285.

5 Смотри «Рекомендательное решение и доклад Первой комиссии для расследования: Открытые вопросы, касающиеся инцидентов в связи с войной в Ираке и борьбой с международным терроризмом» (Первая КПР парламента шестнадцатого созыва), Бундестаг принт 16/13400 (18 июня 2009), 353-418. 
Кундузе, Афганистан, в сентябре 2009 года. ${ }^{6}$ В 2012 году была учреждена другая комиссия, чьей задачей было расследовать неонацисткую банду, так называемую «Ячейки из Цвикау», чьи преступления оставались нераскрытыми в течение многих лет. ${ }^{7}$

В отличие от этих случаев, есть связанные с безопасностью проблемы, которые стали предметом публичного обсуждения, но никогда не дошли до уровня парламентского расследования. В этом контексте министр обороны Германии в то время и Координатор разведывательных служб в ведомстве федерального канцлера Германии подали в отставку в начале 1990-х в связи с несоответствиями при экспорте вооружений из бывшей Восточной Германии. ${ }^{8}$ Другим случаем, который не был расследован парламентской комиссией, был случай журналиста, трафик частной электронной почты которого был непреднамеренно перехвачен федеральной разведывательной службой Германии (ФРС) в 2008 году. ${ }^{9}$ Этим случаем занимался Парламентский контрольный комитет, постоянный орган, который осуществляет надзор за работой разведывательных служб на федеральном уровне. ${ }^{10}$

6 Смотри «Рекомендательное решение и доклад комитета по обороне Первой комиссии для расследования: Расследование приказов военного руководства провинциальной группы реконструкции (ПКР) в Кундузе/Афганистан об осуществлении воздушных ударов против двух цистерн 3 и 4 сентября 2009 года, разведывательной и информационной политики федерального правительства, а также соответствия избранного курса действий национальным и многонациональным политическим, юридическим и военным руководящим документам для миссии в Афганистане» («КПР Кундуз») Бундестаг принт 17/7400 (25 октября 2011), 29, 169.

7 Смотри «Требование об учреждении Комиссии для расследования», Бундестаг принт 17/8453 (24 января 2012).

8 Смотри «Ответ Федерального правительства: поставка вооружений с Востока Федеральной Разведывательной Службой и транзитные поставки в дружественные государства», Бундестаг принт 12/2513 (30 апреля 1992).

9 Смотри «Первая КПР парламента шестнадцатого созыва», 474.

10

Парламентский контрольный комитет отвечает за надзор за федеральными разведывательными ведомствами. Федеральное правительство обязано подробно информировать комитет о деятельности разведывательных служб. Эти консультации строго секретны и не открыты для общественного доступа - смотри www.bundestag.de/bundestag/ gremien/pkgr/index.jsp и Dietmar Peitsch and Christina Polzin, "Die parlamentarische Kontrolle der Nachrichtendienste” [«Парламентский контроль за службами разведки»], Neue Zeitschrift für Verwaltungsrecht (2000): 387-93. Стоит упомянуть, что большинство государств не располагает независимым парламентским надзором за разведывательными службами, а только контрольными органами в соответствующих министерствах. Смотри Hans Born, "Towards Effective Democratic Oversight of Intelligence Services: Lessons Learned from Comparing National Practices," Connections 3:4 (2004): 1-12, Смотри так же Jelle van Buuren, Secret Truth: The EU Joint Situation Centre (Amsterdam: Eurowatch, 2009). 


\section{Предварительные этапы работы парламентской комиссии}

В прошлом вопросы, связанные с политикой в сфере безопасности, которые в конце концов становились объектом парламентского расследования, обычно не были центром дискуссий на политической арене или в средствах массовой информации, кроме как в случаях незадолго до федеральных выборов или после них. Причиной тому были, с одной стороны, неопределенные результаты самой избирательной кампании, и с другой стороны, потенциальные партийные коалиции правительства и оппозиции, которые будут сформированы после выборов. Ощущение того, насколько интенсивно общественность следит за расследованиями такого типа, может стать поводом для любой оппозиционной партии чтобы найти тему, которая потенциально будет связывать правительство на годы вперед.

Приведем лишь один пример: в конце 2005 и начале 2006 года новое федеральное правительство попыталось воспрепятствовать созданию ПКР, опубликовав доклад, направленный на опровержение обвинений в средствах массовой информации и увеличивающегося числа критических вопросов, связанных с войной с терроризмом в постоянных комиссиях Бундестага (нижней палаты парламента). ${ }^{11}$ Попытка провалилась. В масштабе, которого, вероятно, нигде в мире не было, органы безопасности собрали материал для опровержения критики. Но у оппозиционных партий все равно все еще оставались «открытые вопросы», и в итоге было решено учредить парламентскую комиссию. ${ }^{12}$ Одним из последствий было то, что конфиденциальная информация стала общественным достоянием еще до того, как ПКР начала свою работу.

Создание ПКР на федеральном уровне обычно означает, что десятки, если не сотни, сотрудников затронутых государственных ведомств, а также парламентской администрации, оказываются занятыми на несколько лет. В Берлин для слушаний посылается огромное количество оригинальных и скопированных документов и вызывается огромное число свидетелей, некоторые из них из весьма отдаленных районов.

11 Смотри Dana Priest, “CIA Holds Terror Suspects in Secret Prisons," Washington Post (2 November 2005); доступно на www.washingtonpost.com/wp-dyn/content/article/2005/11/01/ AR2005110101644.html. Федеральное правительство представило окончательный доклад «Об инцидентах в связи с войной в Ираке и войной с международным терроризмом» Парламентскому контрольному комитету 20 февраля 2006 года. Для дальнейшего расследования остававшихся вопросов и для формулирования оценок и возможных последствий, в соответствие с статьей 44 Основного закона, была создана комиссия для расследования.

12 Смотри "The Green Party, the Liberals and the Left Party Decide to Set up a COI to Inquire into the BND Scandal," Der Spiegel online (17 January 2006); доступно на www.spiegel.de/ politik/deutschland/bundestag-gruene-fdp-und-linkspartei-beschliessen-untersuchungsaus schuss-zur-bnd-affaere-a-395748.html. Смотри так же "BND-Ausschuss," Die Zeit online (12 April 2006, доступно на www.zeit.de/online/2006/15/BND. 
Учреждение ПКР и ее соответствие рассматриваемой проблеме, согласно положениям Конституции

В соответствие со статьей 44, параграф 1, раздел 1 Основного закона Германии, предложение о создании ПКР в Бундестаге может быть внесено одной четвертью членов парламента - так называемым «квалифицированным меньшинством». Из этого становится очевидным, что расследование неправомерного поведения и незаконных действий почти всегда возможно, и большинство в Бундестаге не может этому помешать. Таким образом, право на расследование является одним из самых важных демократических прав в Германии. ПКР регламентируются Основным законом и являются частью тех законодательных положений, которые гарантируют меньшинству наибольшее возможное влияние для реализации своей политической повестки дня в рамках коалиционно-оппозиционного структурирования. $^{13}$

Решение создать комиссию принимается в соответствие с конституционным правом. Это означает, что возможность ограничить диапазон расследования путем толкований должна быть соответственно определена. ${ }^{14}$ Бундестаг определяет сколько и кто из его членов будут членами комиссии. Состав отражает численность разных партийных групп в данном парламенте. Как правило, комиссия состоит из семи или одиннадцати депутатов. Председатель комиссии является членом наибольшей парламентской группы, а его или ее заместитель является членом следующей по численности фракции. ${ }^{15}$ Обычно заседания проводятся во время присутственных сессий парламента. Возможно проведение специальных заседаний, но они должны быть одобрены Президентом Бундестага. ${ }^{16}$

Если факты по делу входят в прерогативы Министерства обороны, Комитет по обороне несет ответственность за конституирование себя в качестве ПКР. ${ }^{17}$ Так случилось в парламенте семнадцатого созыва при расследовании событий, связанных с воздушным ударом в Кундузе, Афганистан, в сентябре 2009 года.

13 Смотри Reinhard Bergmann в Grundgesetz für die Bundesrepublik Deutschland-Taschenkommentar [Основной закон Федеральной Республики Германия - Карманный комментарий], Седьмое издание, под ред. Karl-Heinz Seifert and Dieter Hömig (Berlin: Nomos, 2003), 369.

14 Решение создать комиссию для расследования вступает в силу, если расследование соответственно дефинировано. Смотри Конституционный суд Саксонии, 154-I-07 (29 августа 2008), 29; Решения Федерального конституционного суда 124, 78 [117]; Государственный суд Хессе, Решения Административного суда 17, 1 [17]; 22, 136 [140]; Конституционный суд земли Саксония-Анхалт, Решения конституционного суда провинции 15, 353 [358].

15 Смотри разделы 4-7 Акта о комиссиях для расследования.

16 Смотри раздел 8 Акта о комиссиях для расследования.

17 Смотри раздел 34, параграф 4 Акта о комиссиях для расследования; согласно статье 45(a), параграф 3 Основного закона, нельзя создавать комиссии для расследования по вопросом обороны, и нельзя Комитету по обороне давать мандат на проведение расследования. 


\section{Права ПКР и исполнительного органа}

Права ПКР указаны в Акте о комиссиях для расследования немецкого Бундестага, в котором есть ссылки на Уголовно-процессуальный кодекс. ${ }^{18}$ Это означает, что процедура ПКР подобна процедуре уголовного расследования, и в частности того, что касается законности вещественных доказательств и свидетельских показаний. Но все-таки комиссия для расследования не является судом. В итоге она просто составляет доклад, который предоставляется Президенту парламента. ${ }^{19}$

Парламентские фракции могут потребовать выслушать показания свидетелей ПКР. Для этого необходимы голоса одной четверти членов комиссии. ПКР исключительно редко отвергает такие предложения, так как рискует быть обвиненной в препятствовании Парламенту (и, следовательно, общественности) в получении доступа к информации. Но по закону это возможно. Комиссия может сослаться на недопустимость выслушивания, если предложение о выслушивании неправомерно - к примеру, направлено на откладывание расследования, - или предполагает обсуждение вопросов, которые не входят в мандат комиссии. ${ }^{20}$

Федеральное правительство, с другой стороны, обязано помогать ПКР выполнить задачу выяснения фактов. Обязанность сотрудничать следует из принципа, что государственные служащие должны действовать в соответствии со своими конституционными обязанностями, принцип, которого должны придерживаться все конституционные органы. В текущей работе это означает, что любые документы должны быть предоставлены ПКР, даже если их передача может быть политически неудобной. Свидетели из исполнительных органов власти должны говорить в комиссии правду, даже если это входит в противоречие с их политическими и институциональными интересами.

У федерального правительства есть право направлять в комиссию представителей всех департаментов, которые попадают под мандат комиссии, и которые в соответствие со статьей 43, параграф 2 Основного закона вправе присутствовать и выступать на заседаниях комиссии. Однако представители не могут напрямую задавать вопросы свидетелям, вызванным комиссией. Обычно они назначают сотрудника, который представляет позицию правительства. Этот назначенный пред-

18 В соответствие с разделом 36 Акта о комиссиях для расследования есть возможность обратиться к судье Федерального суда. Так случилось при работе комиссии для расследования в парламенте шестнадцатого созыва, причем возражения оппозиции были отвергнуты. Смотри «Первая ПКР парламента шестнадцатого созыва», 48.

19 Работа ПКР, однако, может привести к уголовному расследованию. Свидетели обязаны говорить правду. Если они этого не делают, они могут быть судимы за дачу фальшивых показаний, когда не находились под присягой. § 153 Уголовный кодекс. Смотри еще «Плутониевая ПКР», 25.

20 Смотри разделы 10 и 17 Акта о комиссиях для расследования; и Bergmann в Grundgesetz für die Bundesrepublik Deutschland-Taschenkommentar, ed. Karl-Heinz Seifert and Dieter Hömig, Art. 44, Para. 2 (1), margin no. 6. Требование представить доказательства делает возможным определение на раннем этапе, какого типа доказательства собираются депутаты использовать по данной теме. 
ставитель имеет право спрашивать председателя, если вопросы, задаваемые членами Бундестага, выходят за пределы расследования, или выходят за пределы и нарушают право требовать доказательств. Функция этого представителя подобна той, которую в суде имеет уполномоченный представитель.

\section{Мандат ПКР}

Любой возможный мандат ПКР в основном вписывается в следующую схему:

- К Ко что сделал, когда, как, с кем, с помощью чего и зачем?

- Было ли это законным и/или политически допустимым?

- К Кто из внутренних людей и/или людей, принимающих решения, знал об этом и несет ответственность?

- Каковы уроки случившегося?

Последний вопрос относится только к представителям в Бундестаге, которые делают предложения о будущих действиях в своем окончательном докладе. Однако, предшествующие вопросы необходимы законодательному органу для получения соответствующей информации от органов исполнительной власти. Как правило, мандат ПКР можно интерпретировать дословно. Мандат комиссии определяет, какие факты следует расследовать и где возможно ожидать, что параллельно расследованию начнутся политические дебаты. ${ }^{21}$ Временной период, подлежащий расследованию, начинается с момента, когда вопросные обстоятельства имели место. Конец периода - это дата, когда была создана ПКР. Текущие действия не подлежат расследованию, так как это нарушило бы запрет на сопутствующий контроль. 22

Верхние эшелоны департаментов, вовлеченных в работу ПКР, принимают фундаментальное решение интерпретировать мандат комиссии в широком или в узком смысле. В итоге, они решают, позволить ли большую прозрачность. Широкое толкование мандата приводит к предоставлению большого числа файлов, и потребует допрос свидетелей, которые должны будут отвечать на большое количество вопросов. С другой стороны, узкое толкование означает, что будут рассматриваться небольшое число документов, имеющих отношение к расследова-

21 В этом контексте определенные фразы и понятия могут выглядеть несколько туманными и создавать впечатление неопределенности. Поэтому рекомендуется обращаться к рекомендательным решениям, к протоколам пленарных дебатов и заявлениям отдельных депутатов. Смотри Решения федерального конституционного суда, 124, 78 [118 f.]

22 Смотри Решения Баварского конституционного суда 38, 165 [177]; Böckenförde, Парламентские комиссии для расследования и местная автономия, 1 f.; Achterberg/Schulte Kommentar zum Grundgesetz. [Комментарии к Основному закону Германии], том 2, 4-е издание, под ред. Hermann von Mangoldt, Friedrich Klein, and Christian Starck (Munich: Vahlen, 2000), Art. 44, margin no. 61. 
нию, а свидетели будут отвечать на четко сформулированные вопросы, касающиеся фактов. ${ }^{23}$

\section{Доказательства}

Требования комиссии на предоставление доказательств должны быть должным образом сформулированы и должны служить цели сбора информации. Однако допускается, чтобы требование в какой-то степени было нечетким. Как правило принимается, что перешли границу допустимости, если требование на предоставление доказательств напоминает «выстрел наобум». Для институций исполнительной власти важно, чтобы эти требования касались доказательственного материала, необходимого для выполнения задачи ПКР. Это означает, что требования должны быть как трафареты, которые, если наложить их на миссию ПКР, будут показывать конкретные аспекты, для которых они требуют материальных доказательств или свидетельских показаний.

К примеру, рассмотрим требование ПКР, которое комиссия издает в начале своей работы или каждый раз, когда она раскрывает новый комплекс обстоятельств. Когда члены комиссии следуют линии расследования «кто в какой момент времени что знал, от кого, о наличной разведывательной информации, мотивах, об осуществлении и последствиях воздушного удара», соответствующее требование будет включать все дела, документы, корреспонденцию и т.д., имеющиеся в наличии во всех ведомствах, которые потенциально причастны к случаю. Этот простой пример показывает, что все затронутые части сектора безопасности, если это возможно, попытаются собрать все наличные имеющие отношение к миссии ПКР документы и записи и представят их в парламент для выяснения дела. ${ }^{24}$

Но ключевым является вопрос, что следует считать имеющим отношение к предмету расследования? Это разделение имеет не только юридический, но и практический смысл. Информация, которая не имеет отношения к предмету расследования, не является частью расследования, и следовательно, ее не нужно предоставлять комиссии. Для парламента является незаконным проводить слишком обширное расследование. К примеру, если бы в контексте расследования воздушного удара в Кундузе комиссия потребовала бы от Министерства обороны и

23 Эти основные рекомендации, однако, допускают интерпретации в практических целях. Хотя во время «Первой ПКР парламента шестнадцатого созыва», парламенту ясно было сказано, что из-за характера данного случая, правительство может разрешить только ограниченную степень прозрачности, он получил полную, безусловную и щедрую поддержку в случае комиссии по Кундузу.

24 Дело усложняется, когда комиссия решает получить определенное доказательство во время уже начавшегося расследования. Свидетель может сделать заявление о действиях, которые до этого не рассматривались, как имеющие отношение к предмету расследования, или просто о них не было известно. Обычно комиссия проявляет интерес к таким неожиданным поворотам, что делает необходимым потребовать новые доказательства, которые могут привести к новым раскрытиям. 
Вооруженных сил Германии предоставить все документы, касающиеся Афганистана, это было бы злоупотреблением полномочиями.

Вопрос, кто определяет, что является имеющим отношение к задаче расследования ПКР, стал спорной конституционной проблемой в парламенте шестнадцатого созыва и был внесен в Конституционный суд. ${ }^{25}$ В июле 2009 года Федеральный конституционный суд вынес решение, что толкование федеральным правительством вопроса о том, что имеет отношение к задаче расследования, нарушило права ПКР. Конституционный суд не дал исполнительной власти право решать, какие документы содержат информацию, имеющую отношение к расследованию Бундестага, и какие такую информацию не содержат. Однако, следуя реалиям фактического обладания информацией, исполнительная власть продолжает де факто осуществлять право на толкование. Это возможно из-за обязанности Бундестага четко определить мандат ПКР. В итоге оказывается, что негласный компромисс лучше всего был бы в интересах обеих сторон. В большинстве случаев такой компромисс является очевидным решением. К примеру, для расследования не является продуктивным требовать информацию о всей деятельности на Балканах, если единственным имеющим отношение к расследованию аспектом является вопрос кто, что и когда знал о задержании подозреваемого террориста в Боснии и Герцеговине.

Конституционный суд не ответил на вопрос, может ли ПКР требовать полной информации о существующих файлах. Хотя члены комиссии в принципе знают номера файлов из представленных им дел, но никто никогда не требовал предоставления полных дел. Возможно, это объясняется опасением членов Бундестага, что они будут завалены папками и документами. Предварительный отбор файлов, касающихся расследования, обеспечиваемый государственными ведомствами, выглядит более продуктивным. Настаивать на полном ознакомлении со всеми событиями действительно было бы менее полезным, так как это привело бы к тому, что исполнительные власти будут обязаны отпечатать все пресс-релизы, касающиеся обсуждаемой темы. Число папок увеличилось бы драматически.

Но все-таки решение Конституционного суда укрепило заинтересованность парламента в открытии соответствующих файлов. В решении указано, что исполнительные власти не могут сами принимать решения относительно прозрачности, когда дело касается чувствительной информации.

\section{Право органов исполнительной власти отказывать в предоставлении документов}

Вопрос о том, существуют ли доказательственные материалы, доступ к которым может быть отказан комиссии на правном основании, является еще одним фактором, создающим напряжение в нахождении баланса между предоставлением и отказом в предоставлении информации. Границы права получать доказательственные материалы также были предметом противоречивого обсуждения в парламенте

25 Решения Федерального конституичионного суда 124, 78 [118f.] 
шестнадцатого созыва. Это сыграло определенную роль в прежде упомянутом случае, по которому высказался Федеральный конституционный суд. В нескольких предшествовавших случаях Конституционный суд определил обстоятельства, при которых исполнительные власти могут сослаться на свое право отказать в доступе к определенным документам при парламентском расследовании. Но для комплексных расследований комиссии во время парламента шестнадцатого созыва предшествующие решения суда давали только самые общие указания. Оппозиция ухватилась за эту возможность и использовала некоторые файлы, в доступе к которым было отказано для того, чтобы потребовать от Конституционного суда вынести решение об охвате права парламента проводить расследования в связи с ограничениями на право получать доказательственные материалы. ${ }^{26}$ Они также атаковали сильные ограничения, наложенные на свидетелей из государственных ведомств, которым разрешено давать показания перед комиссией. Это был еще один случай, в котором Конституционный суд укрепил право Бундестага получать информацию вразрез с интересами ведомств исполнительной власти. С другой стороны, Конституционный суд решил, что ограничения прав парламента, на которые ссылается федеральное правительство, не являются per se (сами по себе) незаконными.

В результате сторона правительства переформулировала разрешения на свидетельствование и требования на предоставление оснований так, чтобы они соответствовали решению суда. Прозрачность стала приоритетом в случаях, при которых раньше комиссии было бы отказано в доступе к документам. Однако, в доступе к некоторым частям документов или к целым документам парламенту может быть отказано на следующих основаниях: в целях Staatswohl (национальных интересов); в основных сферах ответственности исполнительной власти; на основании основных гражданских и человеческих прав и по причине отсутствия права на распоряжение частью предоставляемой информации. ${ }^{27}$

Конституционный суд не оспаривал право на отказ предоставлять доказательственные материалы по причине национальных интересов per se, но решил не делать дальнейших уточнений по этому вопросу. ${ }^{28}$ В этом контексте предполагается, что доказательственные материалы могут быть не предоставлены комиссии - и таким образом и общественности, - если они раскрывают факты, которые могут нанести вред национальной безопасности или жизненно важным интересам одной из шестнадцати федеральных провинций. Полагается, что такая возможность существует, если публикация документов может оказать влияние на существование или функционирование государства, угрожать внутренней и внешней безопасности или приведет к массовым нарушениям общественного порядка и безопасно-

26 Решения Федерального конституционного суда 67, 100 [142]; 76, 363 [387]; 77, 1 [46 f.] и «Первая ПКР парламента шестнадцатого созыва», 48, 419, 478.

27 Смотри «Первая ПКР парламента шестнадцатого созыва» 24: «Число предоставленных файлов».

28 Решения Федерального конституционного суда 67, 100 [134] и Решения Федерального конституционного суда 124, 78 [123]. 
сти. Однако, суд уточнил, что такой угрозы не существует, если публикация причинит просто неудобство правительству. Кроме того, суд указал, что за Staatswohl в равной мере отвечают правительство и Бундестаг, и что защита чувствительной информации должна осуществляться посредством засекречивания. ${ }^{29}$ В аргументации было указано, что Бундестаг, со своей стороны, так же должен считаться с безопасностью, защитой и правилами работы с информацией в соответствии со степенью ее секретности. Однако, решение от июля 2009 года не учитывает множество публикаций в прессе, которые основываются на утечке документов.

И все-таки, непредоставление информации с целью защиты национальных интересов останется исключением из правила. В таких случаях правительство обязано очень внимательно взвесить все «за» и «против» непредоставления доказательственного материала и тщательно объяснить свое решение в письменном виде. За последние несколько лет в понимании Staatswohl сформировались субкатегории, что привело к тому, что власти отказывают раскрывать определенные документы. Это в основном случаи, которые затрагивают основные области ответственности исполнительной власти, случаи защиты процесса дипломатических переговоров, и в особенности, защиты методов работы разведывательных служб. Этот последний пункт имеет важнейшее значение для служб разведки вследствие их естественного желания сохранять секретность своих методов.

Основные области ответственности исполнительной власти включают то, какие инициативы, консультации и действия возможны. Как правило, они недоступны для ПКР. ${ }^{30}$ И как правило, правительство не должно быть под постоянным надзором, а его члены должны иметь возможность свободно подготавливать и принимать решения без вмешательства оппозиции. Эта защита гарантирована предположением, что существуют недоступные «тайные сферы» ответственности исполнительной власти. Это, в частности, относится к обсуждениям в кабинете и к подготовке решений кабинета и парламента. Нет никаких сомнений в легитимности такого предположения; существуют, однако, разногласия в том, какие доказательственные материалы попадают под эту категорию. Учитывая уточнения Конституционного суда и опыт предшествовавших комиссий, можно сказать, что понятие основной области защищает доказательства, которые связаны с процессом

29 Федеральный конституционный суд ранее решил, что допустимо применять правила засекречивания и к частному сектору. Смотри Решения Федерального конституционного суда 67, 100 [135] и § 1, Правила для процедур Бундестага.

30 Решения Федерального конституционного суда 67, 100 [133 f., 139 f.]; 110, 199 [214]; 124, 78 [120]; см. например Volker Busse, "Der Kernbereich exekutiver Eigenverantwortung im Spannungsfeld der staatlichen Gewalten” [«Основная область автономии исполнительной власти в среде конфликтующих приоритетов различных государственных властей»], в Die öffentliche Verwaltung 42 (1989): 45. 
принятия решений или с проблемами, по которым решение еще не принято. ${ }^{31}$ Но определить, как точно проводить классификации такого типа очень трудно. Как правило, можно считать, что досье по данному вопросу закрыто тогда, когда процесс принятия решения правительством достиг определенной степени зрелости или формирование внутреннего мнения закончилось и результаты готовы для предоставления на внешнее рассмотрение. Хотя иногда, к примеру, существует официальная финализирующая директива как завершение документации, в других случаях есть неопределенности. Множество индивидуальных досье, связанных с войной с терроризмом, к примеру, не будут закрыты в обозримом будущем. В этой связи, исполнительная власть может настаивать на том, что интерес парламента в определенном расследовании влияет на текущие досье. На деле, в этой связи должен быть дан ответ на вопрос: окажет ли раскрытие влияние на процесс принятия решения в связи с текущей и будущей функциональностью и в связи с дискретностью принятия решения? В некоторых случаях, перевешивает ли заинтересованность в сохранении конфиденциальности заинтересованность парламента в данном расследовании? Положительный ответ в обоих случаях должен быть тщательно обоснован. Заинтересованность парламента в расследовании обычно имеет больший вес в сценариях, когда расследованию подлежат очевидные нарушения закона. Парламент может основываться на такой аргументации как раз в случаях, связанных с внешней политикой и политикой в сфере безопасности.

Конституционный суд принял решение, что непредоставление материалов, выработанных при подготовке сессий Бундестага или при подготовке разговоров с представителями чужих государств, недопустимо. ${ }^{32}$ Члены суда раскритиковали официальные письма правительства с отказом за то, что они недостаточно конкретны и сочли, что перевешивание интереса в конфиденциальности не имело места. Поэтому Конституционный суд еще раз вынес решение в пользу прозрачности, отдавая ей предпочтение перед аргументами исполнительной власти, касающимися конфиденциальности.

B-третьих, правительство ссылалось на возможное нарушение основных гражданских и человеческих прав, которое может стать следствием практики полного

31 Это применимо к протоколам федерального кабинета, к заметкам кабинета и к материалам, облегчающим процесс принятия решений, пока на основании этого досье не было принято политическое решение. Смотри Решения Федерального конституционного cуда 124, 78 [122 f., 129 f.]

32 Смотри Решения Федерального конституционного суда 124, 78 [170 ff.] по «Первой ПКР парламента шестнадцатого созыва». 
и открытого доступа к документам. ${ }^{33}$ В частности, это касается фундаментального

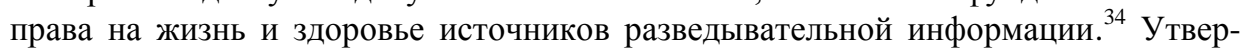
ждается, что после раскрытия во многих государствах источнику угрожает жестокое наказание или длительный срок заключения. В этом случае заинтересованность парламента в получении информации надо взвесить с учетом опасности возможного нарушения фундаментальных прав. В случаях, когда ПКР отказано в доступе к информации на таком основании, правительство должно представить основательное объяснение почему в письменном виде. ${ }^{35}$

Последней, хотя и спорной причиной, для непредоставления доказательственного материала, является отсутствие права распоряжаться определенными частями информации в письменном виде. Это касается сообщений, полученных немецкими разведывательными службами от иностранных служб с поставленным в явном виде условием не раскрывать их третьей стороне. ${ }^{36}$ Применение этого конкретного юридического барьера на получение доказательственного материала имеет очень важное значение для всех федеральных и местных служб, независимо от уровня секретности. Это в принципе касается всей информации, полученной с явным требованием, или при негласном предположении, что она будет распространяться только с согласия источника. ${ }^{37}$ Есть мнение, что запрет на передачу такого рода информации номинально попадает под запрет на основании Staatswohl (национальных интересов). Можно утверждать, что защита так называемого «правила третьей стороны» в конечном итоге служит национальным интересам, так как нарушение этого правила будет означать, что страна в глазах своих союзников

33 В службах безопасности, это право требовать предоставление данного доказательства может быть связано с правом на жизнь и физическую безопасность, с общими правами личности и с правом на информационное самоопределение. Смотри Решения Федерального конституционного суда 67,100 [144]. Смотри так же Dieter Hömig, в Grundgesetz für die Bundesrepublik Deutschland-Taschenkommentar, 7-е издание, под ред. Karl-Heinz Seifert and Dieter Hömig, Art. 10, Para. 1, margin no. 1a.

34 Смотри Нӧmig, в Grundgesetz für die Bundesrepublik Deutschland-Taschenkommentar, 7-e издание, под ред. Karl-Heinz Seifert and Dieter Hömig, Art. 10, Para. 2, margin no. 5 f.

35 Смотри Решения Федерального конституционного суда 124, 78 [123f.], и Решения Федерального конституциионого суда 67, 100 [142]. Другой проблемой, которая подлежит проверке, является вопрос, можно ли гарантировать основные права путем категоризации в соответствие с Общими административными положениями Федерального министерства внутренних дел об организационной защите классифицированных документов от 31 марта 2006 года.

36 Право на информационное самоопределение может быть ограничено, только если это в интересах общества и строго придерживаясь принципа пропорциональности. Ограничение не должно идти далее, чем необходимо для защиты общественных интересов; смотри Решения Федерального конституционного суда 124, 78 [125].

37 Информацию, которая была получена от третьего государства-члена или от третьей страны, можно обменивать между правоохранительными органами двух государств-членов только с согласия этого третьего государства. Смотри http://europa.eu/legislation_ summaries/justice_freedom_security/police_customs_cooperation/114581_en.html. 
становится в меньшей степени заслуживающей доверия. В результате, международные партнеры Германии постепенно перестанут делиться с Германией чувствительной информацией. Это, в свою очередь, драматически ухудшит способность Германии, к примеру, бороться с терроризмом. ${ }^{38}$

Сказанное выше еще раз доказывает, что Конституционный суд накладывает строгие ограничения на возможность исполнительной власти удерживать доказательственные материалы на основании соображений безопасности. Однако, в реальной работе ПКР считается нормальным, когда неопределенность, касающаяся соответствия и границ права получать доказательственные материалы, возникает и остается неразрешенной в течение нескольких месяцев. Деэскалацию противостояния можно обеспечить с помощью, к примеру, так называемой «председательской процедуры», или передачей документов без подтверждения каких бы то ни было юридических обязанностей, или неофициальным обсуждением спорных пассажей. ${ }^{39}$

\section{Подборка файлов}

С одной стороны, федеральное правительство обязано предоставлять свидетельства, затребованные ПКР настолько быстро, насколько это возможно, и в комплексном виде. С другой стороны, государственным ведомствам необходимо определенное время, чтобы собрать обширные досье, содержащие документы, необходимые для принятия данного решения. Как было упомянуто выше, файлы, которые предоставляются ПКР, включают все документы, которые можно найти в

38 Разрешение на передачу информации такого типа следует требовать специально. В большинстве случаев такие требования остаются без ответа. Случается, однако, что партнеры явным образом дают разрешение на передачу информации или запрещают ее. Смотри Jan Hecker, “Anmerkung zum BVerfG-Beschluss vom 17.06.2009” [«Комментарии решения Федерального конституционного суда от 17 июня 2009»], Deutsches Verwaltungsblatt 19 (2009): 1239 ff. Смотри еще Решения Федерального коституичионного суда 124, 78 [123 f.]. Можно также полагать, что отсутствие права на распространение не является достаточной причиной, чтобы скрывать информацию. Если власти не могут предоставлять свободно информацию, они не открыты для инспектирования со стороны парламента.

39 При председательской процедуре, когда только председатель и заместитель председателя имеют полный доступ к секретному материалу, маленькой группе депутатов может быть предоставлена возможность прочитать спорные пассажи и проверить, имеются ли достаточные доводы для непредоставления информации. Однако, Конституционный суд не принимает эту процедуру как альтернативу детальной и обоснованной оценке всех «за» и «против» в случае упомянутых выше ограничений на получение доказательственных материалов. Смотри Решения Федерального конституционного суда 67, 100 [138f.]; 77, 1 [56]. Другим механизмом для деэскалации напряжения является ex gratia (добровольная) консигнация документов. Он так же используется при выслушивании свидетелей, если остается неясным, входят ли комментарии о фактах и обстоятельствах в охват расследования. Однако, если такая процедура станет рутинной, она может иметь отрицательные последствия. 
официальных делах, касающихся досье, входящих в охват требования о предоставлении доказательств. ${ }^{40} \mathrm{~B}$ их число могут входить записки, доклады руководству, доклады экспертов и т.д. В разрез с ожиданиями непосвященных людей, это означает, что не существует комплект изначально готовых зажимных папок, которые просто надо взять с полки и передать Бундестагу. Подборка материалов для таких папок вручную может поначалу показаться тривиальной задачей. Однако, именно эта процедура объясняет огромную трату времени и персонала на предоставление информации. Так как весь процесс добавления разделителей, объяснительных записок, нумерация страниц и написание комментариев относительно классификации и причин для изъятия выполняется вручную, можно себе представить все сложности, которые могут возникнуть в процессе подборки многотомных дел.

Этот трудоемкий процесс, наряду с необходимостью консультироваться с другими затронутыми ведомствами относительно содержания файлов, способствует задержке во времени. В основном применяется ведомственный принцип: отдельные департаменты составляют свои соответствующие подборки документов по собственному разумению. В случаях, когда предварительно осуществлялся обмен информацией, касающейся фактов случая, необходима координация. Тогда сотни писем и ответных писем, повторений и копий приходится проверять на соответствие. Надо иметь согласованность редактируемых пассажей текстов, классификации, деклараций причин непредоставления доказательств, связанных документов и того, какие из документов передаются и какие нет. Все это может казаться

40 «Файл» дефинируется как подборка документов, относящихся к одному вопросу, которая трактуется и цитируется как одно целое и обычно имеет номер файла. Идея состоит в том, чтобы располагать всей письменной информацией по вопросу в любое время. Это отвечает требованию предоставлять свидетельства в письменной форме (документальный характер), которое основывается не только на существовании, но и на доступности документов. Регистр файлов обеспечивает возможность прослеживаемости файлов. 
весьма тривиальным на первый взгляд, но это так же является очень интенсивным усилием для того, чтобы разобраться до конца в рассматриваемой проблеме. ${ }^{41}$

Надо иметь в виду, что соответствующие ведомства часто считают, что к фактам данного вопроса имеют отношение множество файлов. Можно себе представить количество человеко-часов, которое необходимо, когда три или четыре министерства и подчиненные им агентства имеют желание согласовать сотни страниц с файлами из других отделов. Прошлый опыт показал, что обычно некоторые из документов становятся предметом обсуждения в течение весьма длительного времени и часто являются поводом для значительных споров. Другими словами, отдельные департаменты, имеющие отношение к расследованию, не могут обеспечить согласованную подборку файлов, просто «быстро просмотрев» архивы.

До сих пор никогда не было жалоб насчет отличий в стиле, структуре, форматировании и т.д. документов. Это не удивительно, учитывая, что документы изучаются людьми, которые никогда до этого углубленно не занимались вопросными событиями. В итоге, полного и совершенного согласования между разными наборами файлов никогда нельзя достичь. Объем документов и файлов легко может превысить количество пятисот папок. Полного согласования аморфного содержания такого количества файлов вряд ли можно добиться. Трудно представить себе, что служитель министерства по истечении нескольких месяцев может вспомнить какие пассажи были вырезаны из документа другого ведомства. И тем более этого нельзя достичь в парламентской среде. Кроме того, административные практики федерального правительства и его департаментов per se (сами по себе) вряд ли могут стать объектом расследования. Но для того, чтобы достичь высоких стандартов в своей административной работе, правительство должно и далее стремиться к тому, чтобы избегать несоответствий в записях, насколько это возможно.

41 Смотри «Комиссия обнаруживает, что в службах безопасности царит хаос», на www.bundestag.de/dokumente/textarchiv/2013/42632406_kw05_pa_2ua_nsu/index.html; «Требование на создание ПКР», принт Бундестага 17/8453 (24 января 2012); «Промежуточный доклад ПКР 5/1: Возможные нарушения правил органами правопорядка и службами безопасности федеральной провинции Тюрингия, в том числе ответственными министерствами и их политическим руководством, а также лиц, сотрудничающих со службами безопасности (человеческие ресурсы) в контексте действий правого крыла экстремистских структур, в частности Национал Социалистическим Подпольем (НСП) и «Защиты Тюрингского Отечества» (3TO) и их членов, как и возможные ошибки, допущенные службами безопасности Тюрингии и органами охраны правопорядка при расследовании и судебном преследовании преступлений, совершенных НСП и связанных с ним сетей». Это стало очевидным, когда ПКР собирала доказательственные материалы в связи с убийствами, совершенными террористической группой Национал Социалистического Подполья, так называемой «Ячейкой из Цвикау». Рассмотреть нарушения, допущенные разными властями, было одной из задач комиссии, наряду с обзором записей в том виде, в каком они были в то время. Ландтаг Тюрингии, принт 5/5810; смотри еще «Мы буквально не знаем ничего», Süddeutsche Zeitung (14 сентября 2012); доступно на http://www.sueddeutsche.de/politik/pannen-bei-nsu-ermittlungen-wir-wissenbuchstaeblich-nichts-1.1467718. 


\section{Выступление в качестве свидетеля на заседаниях комиссии}

Показания свидетелей являются второй по важности опорой при изучении фактов, имеющих отношение к расследованию. В принципе, ПКР требует назвать свидетелей, которых нужно выслушать по делу, издавая приказ о предоставлении доказательственных материалов. В этом контексте органы безопасности должны гарантировать, что будут номинированы те из их сотрудников, которые располагают соответствующими наблюдениями в рамках своих служебных обязанностей. В обратном случае пришлось бы включить в список всех их служителей, так как обсуждаемые события обычно известны благодаря средствам массовой информации.

Согласно разделу 23 Закона о комиссиях для расследования, в связи с разделом 54 Процессуально-уголовного кодекса (ПУК), должностным лицам - т.е. каждому гражданскому служащему, работающему в секторе безопасности Германии необходимо разрешение для дачи показаний, охват которых обсуждался Конституционным судом. Тогда как в прошлом разрешения на дачу показаний были весьма узко дефинированы, с июля 2009 года их формулировки стали более абстрактными, с тем, чтобы обеспечить открытость исполнительной власти в связи с увеличенной заинтересованностью в прозрачности. ${ }^{42}$ Иностранные должностные лица, как правило, также получают разрешение от своих ведомств. До сих пор большинство попыток комиссий для расследования получить разрешение на выслушивание, в частности сотрудников ведомств США, были неуспешными. Не углубляясь далее в этот вопрос, можно только добавить, что правительство США дало понять, что будет нельзя выслушивать перед Бундестагом в качестве свидетелей также и его бывших сотрудников. ${ }^{43}$ Лица, которым стали известны факты, имеющие отношение к расследованию, другим, неслужебным путем, никоим образом не обязаны давать показания.

С точки зрения средств массовой информации, показания свидетелей является наиболее интересной частью сбора доказательств. Члены Бундестага пользуются возможностью изложить свою позицию перед камерой до или после свидетельских показаний. При голосовании с большинством в две трети и при согласии свидетелей есть возможность передавать сессии по телевидению в живом эфире. ${ }^{44}$

42 Теперь свидетелям нужно привести очень основательные причины для объяснения, почему в таком случае право на требование показаний ограничено. Для экспертов в области права это не проблема, но для тех, кто не знаком с положениями конституции, это весьма затруднительно.

43 Смотри «ПКР Кундуз», 22: «Выслушивание иностранных свидетелей».

44 Смотри статью 44, параграф 1 Основного закона: «Весь процесс получения доказательств является публичным». В Акте о комиссиях для расследования сказано, что запрещена аудио и видео запись и что, как правило, радио- и телепередачи так же запрещены. Исключения, однако, возможны, если большинством в две трети присутствующих членов комиссия решит иначе, и если свидетель или свидетели согласны. Смотри Решение 2-ой ПКР («ПКР Виза»), принт Бундестага 15/5975 (2 сентябрь 2005), 41: «Разрешение на аудио- и видеозапись и заснятия на пленку». 
Председатель открывает выслушивания свидетелей и информирует свидетелей об их правах и обязанностях. ${ }^{45}$ Время, предоставленное членам комиссии на высказывания или на задавание вопросов, зависит от величины их фракции в парламенте. Члены управляющей коалиции и оппозиция поочередно расспрашивают свидетелей. Эта техника чередования называется «Берлинским часом». ${ }^{46} \mathrm{Ee}$ можно повторять так часто, как окажется необходимым. В конце члены комиссии имеют возможность задавать вопросы на открытом форуме.

Когда призываются свидетели, это имеет важное и часто оспариваемое значение в комиссии для расследования. В целом, комиссия пытается придерживаться определенной драматургии, т.е. сначала выслушиваются должностные лица на низших позициях и другие свидетели, затем комиссия поднимается выше по служебной лестнице от глав отделов до заместителей министров ${ }^{47} \mathrm{C}$ точки зрения средств массовой информации, кульминацией слушаний являются показания затронутых министров, которые должны оправдывать действия (или бездействие) правительства, касающиеся предмета расследования. ${ }^{48}$

Сессии всегда начинаются как публичные сессии, если они не закрыты для публики с самого начала. Это часто бывает, когда выслушиваются сотрудники разведывательных служб. ${ }^{49}$ Закрытие для публики определяется в соответствии с разделом 14, параграфы 1 и 3, и разделом 15, параграфы 1 и 3 Акта о ПКР. При-

45 Смотри § 20, пар. 2, Акт о комиссиях для расследования.

46 Берлинский час - это время высказываний на пленарных заседаниях или в комиссиях на основании мест в парламенте. В настоящее время Берлинский час это - шестьдесят минут, из которых двадцать три отводятся СПГ и ХДС/ХСС соответственно, девять минут либералам, и по семь минут Партии Зеленых и Левой Партии. Если время истекло, председатель просит говорившего закончить, а затем его прерывает. Смотри Hermann Schreiner, "Die Berliner Stunde-Funktionsweise und Erfahrungen: Zur Redeordnung des Deutschen Bundestages” [«Берлинский час - как он работает: правила для ораторов в немецком Бундестаге»], в Zeitschrift für Parlamentsfragen 36:6 (2005): 573-88.

47 Смотри «ПКР Кундуз», 18: «Последовательность слушаний и рекомендательные решения» и доклад Второй ПКР: «Расследование роли Бундестага, и в частности, Федерального министерства финансов в заседаниях, касающихся Нуро Real Estate (НуроReal-Estate IC)», принт Бундестага 16/14000 (18 сентября 2009), 35: «Последовательность слушаний».

48 Случается, что члены от коалиции и члены от оппозиции не могут достичь согласия о том, когда вызвать определенных свидетелей. Обычно вызов осуществляется в соответствии с так называемой процедурой «молнии»: каждая из сторон делает предложение, кого выслушать, пока не дойдут до министров. Есть и другие методы, как например, вызов определенного числа свидетелей в соответствии с размером фракции или в отношении один от коалиции, один от оппозиции.

49 Как правило, только небольшое число посетителей заинтересовано в слушаниях. Представители средств массовой информации, однако, обычно присутствуют на заседаниях, когда выслушивание свидетелей обещает быть интересным. Аудио- и видеозапись запрещены. До начала сессии, однако, запись разрешена, так что обычно фотографии показывают министров или высших должностных лиц на месте свидетеля. 
чины, указанные в этих текстах, не допускают никакой возможности выбора. ${ }^{50}$ Засекречивание сессии зависит от сущности обсуждаемого вопроса. Для принятия такого решения достаточно обыкновенное большинство членов комиссии. Согласно разделу 12, параграф 3 Акта о ПКР, высказывания на закрытых слушаниях не могут быть доведены до сведения общественности отдельными членами комиссии; только комиссия в целом может сделать эту информацию публичной. ${ }^{51} \mathrm{Bce-}$ таки иногда после заседания индивидуальные депутаты вкратце информируют средства массовой информации о слушаниях. Однако, защитить классифицированные материалы, гарантировать документальную безопасность и получить необходимую степень засекречивания возможно в соответствии с разделами 15 и 16 Акта о ПКР. Выслушивание показаний, которые классифицированы как конфиденциальные или еще более секретные, происходит в другой комнате, в которой обеспечена безопасность. ${ }^{52}$

Иногда делается запрос на деклассифицирование, так, чтобы показания свидетелей и протоколы ПКР могли бы войти в записи публичных слушаний свидетелей. $^{53}$ Это может способствовать обсуждению в средствах массовой информации касательно нарушений в прошлом. До сих пор правительство всегда шло навстречу требованиям парламента. В результате органы безопасности должны проверить все классифицированные протоколы и гарантировать, что после редакции чувствительных пассажей их можно опубликовать. Это часто подразумевает сотни

50 Согласно параграфу 14 Акта о комиссиях для расследования, присутствие публики исключается, если в ходе допроса будет выноситься личная информация свидетелей и третьих лиц, и если публичное обсуждение этих вопросов может навредить важным интересам затронутых сторон; может угрожать жизни, здоровью или свободе отдельных свидетелей или других лиц; или если обсуждение бизнеса, профессии, изобретений или возможное раскрытие налоговой тайны нанесут вред законным интересам или навредят федерации или провинции, и в частности безопасности федеральной республики, или затрагиваются ее отношения с другими государствами.

51 Каждый из членов комиссии может информировать общественность о консультациях и решениях во время заседания по сбору доказательственных материалов, если сессия категоризирована как всего лишь «непубличная». Для эффективной защиты секретов и классифицированных материалов, которые проистекают из сферы правительства и во время выслушивания свидетелей станут публичным достоянием, необходима дополнительная защита. Такая физическая и процедурная защита гарантирована параграфами 15 и 16 Акта о комиссиях для расследования, если надлежащим образом проведена соответствующая классификация.

52 Смотри 14 Акта о комиссиях для расследования и §9 Акта о комиссиях для расследования Берлинской камеры депутатов.

53 ПКР решает, когда показания свидетеля классифицированы; смотри $\S 15$, параграфы 1 and 2, в связи с $\S 14$, параграф 3 Акта о комиссиях для расследования. Решение обычно основывается на степени секретности соответствующего материала. Публикация документов ПКР подчиняется только подзаконным актам Бундестага. Будут ли рассекречены протоколы слушаний, зависит единственно от ПКР. В таких случаях правительство должно настоять на участии в принятии решения. 
страниц и касается множества ведомств. Таким образом, координация предложений между разными службами безопасности относительно того, какие тексты следует редактировать, может быть утомительной.

Как было объяснено выше, свидетель может сослаться на ограниченный охват разрешения давать показания как на причину для отказа ответить на конкретный вопрос. Свидетель так же может отказаться отвечать на любые вопросы спекулятивного или гипотетического характера и может придерживаться своих наблюдений и того, что он знает из первых рук. ${ }^{54}$ Члены ПКР, однако, могут спросить свидетеля об его оценке событий или личностей, даже если такая оценка является абстрактной. Если свидетель не желает давать показания по конкретному вопросу перед комиссией, или считает, что границы права давать показания были достигнуты, координатор, представляющий федеральное правительство, будет обязан представить основательное оправдание для этого. ${ }^{55}$

\section{Утечка информации}

Онлайн медиа, телевидение, печатные средства массовой информации пристально следят за событиями, связанными с заседаниями комиссии. Почему сектор безопасности снова и снова попадает в прицел парламентских расследований, является предметом предположений. События с участием тайных агентов, война, тайные операции, ЦРУ, преследование террористов и т.д., похоже, все еще привлекают в определенной степени внимание средств массовой информации. Это понятно с публичной точки зрения, так как эти темы, очевидно, предлагают в некотором роде драматическую историю, которую сухие и сложные процессы в финансовом и экономическом секторе никогда не могли бы создать. ${ }^{56}$ Кроме того, они предлагают журналистам множество возможностей углубиться в вопросы «Кто что знал и когда он это узнал», касающиеся людей, принимающих политические решения. В конце концов, это еще одна грань желания общества и парламента расследовать случаи нарушений, коррупции и неправомерного использования фондов. ${ }^{57}$

Во время работы нескольких последних ПКР, которые занимались вопросами внешней политики и политики в сфере безопасности, в печати появилось несколько публикаций, ссылающихся на документы, которые были посланы в секре-

54 Обязанность давать показания применима только в отношении фактов, но не оценок, заключений, юридических вопросов, общих впечатлений, предположений, опыта и т.д. Вопросы, относящиеся к чему-нибудь другому, чем к фактам, могут быть отклонены как недопустимые.

55 Когда свидетель дает показания перед ПКР, он не обязан говорить то, что может быть использовано против него. Однако, согласно § 22 Акта о ПКР, причины для отказа должны быть выяснены. Для этого нужны достоверные факты - простого заявления недостаточно. Смотри Решения Федерального конституционного суда 124, 78 [131f.].

56 Смотри, к примеру, "Нyро Real Estate Committee"; "The Process of an Inquiry," 26 ff.

57 Hans Born, "Towards Effective Democratic Oversight of Intelligence Services: Lessons Learned from Comparing National Practices, Connections 3:4 (2004): 11. 
тариат комиссии совсем недавно. ${ }^{58}$ Все эти документы имели определенный уровень секретности. Как некоторые из сильно ограниченного количества копий этих документов попали в руки журналистов, так и не было установлено. В этой связи Бундестаг декларировал, что доступ к секретным документам, круг уполномоченных лиц и сохранение секретности в Канцелярии секретных документов в достаточной степени урегулирован ПКР. ${ }^{59}$

Поскольку содержание этих документов немедленно стало общественным достоянием, их легко можно было цитировать во время заседаний комиссии. Правительство продолжало утверждать, что публикация документов не меняет уровень их секретности, хотя эти возражения часто не находили должного внимания при публичных дебатах. ${ }^{60}$ При этом свидетели иногда попадали в неудобное положение. Часто они сталкивались с газетными статьями, публично цитирующими классифицированные документы, тогда как степень секретности исходной информации не была изменена. После этого исполнительная власть начала учитывать, что каждый секретный документ, который предоставлен ПКР, может стать известен и прессе. Документы, которые классифицированы как «конфиденциальные» или с более высокой степенью секретности, далее посылались исключительно в Канцелярию секретных документов Бундестага. Это показывает, что с одной стороны, утечка информации стимулировала публичное обсуждение во вред интересам безопасности с точки зрения исполнительной власти, но с другой стороны, власти реагировали на новые обстоятельства, начав применять более рациональный процесс предоставления файлов и принятием административных мер, которые как минимум замедлили доступ к чувствительным документам.

Независимо от Процедурных правил Бундестага, остается вопрос, попадает ли такое нарушение секретности в сферу действия уголовного права и следует ли его наказывать в соответствие с уголовным кодексом. Соответствующие юридические положения можно найти в Уголовном кодексе Германии в разделе 203, параграф 2, и в разделе 353 (b), параграфы 1 и 2. Когда дело касается должностных лиц служб безопасности, неразрешенное копирование и распространение документов является уголовным преступлением. Для членов парламента и их сотрудников ситуация другая. В любом случае, уголовное преследование должно быть разрешено Президентом Бундестага.

Обвинить журналиста, который получил информацию от должностного лица, еще более трудно. Заминка в том, что первичное преступление - раскрытие сек-

58 Смотри "First COI of the Sixteenth EP," 51 ff; "The Dilemma of Non-Disclosure."

59 Смотри "First COI of the Sixteenth EP," 51 ff: «Так как оказалось невозможным гарантировать защиты документов, предоставленных федеральным правительством несмотря на коллективные усилия, глава канцелярии объявил, что федеральное правительство вознамеривается предоставлять материалы, классифицированные как конфиденциальные или с большей степенью секретности только при условии, что доступ к ним будет разрешен исключительно в канцелярии секретных документов Бундестага Германии.

60 Смотри § 9, Пар. 1, Административные правила о классифицированных документах; § 3, Пар. 2, Процедурные правила Бундестага. 
ретной информации - может быть совершено только лицом, у которого имеется доступ к классифицированной информации. Предметом обсуждения является вопрос, можно ли предъявить обвинения журналисту в «последующей помощи и соучастии». Как бы там ни было, журналист не обязан называть источник информации. После так называемого «Приговора Цицерон» от февраля 2007 года, источник находится под защитой статьи 5 Основного закона (которая гарантирует свободу прессы). ${ }^{61}$

До сих пор всем заявлениям по такому поводу различными органами прокуратуры было отказано в возбуждении дел. Реакция возмущения исполнительной власти, вероятно, будет встречена недоверием со стороны общественности и средств массовой информации: были выявлены незаконные или неправомерные действия исполнительной власти, как власти могут расследовать парламентариев или журналистов за это?

\section{Прекращение деятельности ПКР}

Деятельность ПКР можно прекращать. Это означает, что расследование заканчивается в конце законодательного срока, независимо от того, были ли установлены все факты или составлен ли был окончательный доклад. ${ }^{62}$ Документация ПКР может содержать многие тысячи страниц. Она состоит из четырех частей»: процедуры, установления фактов, оценки и приложения. Секретариат предоставляет начальный вариант доклада парламентским партиям для комментариев. Никакого официального участия федерального правительства не предвидится.

После принятия Бундестагом доклад должен быть опубликован. Для органов безопасности это означает, что сомнительные в смысле секретности пассажи, которые не были редактированы заранее, станут доступны публике. Возможно, что некая классифицированная информация не будет устранена из проекта доклада.

61 В своем вердикте (Решения Федерального конституциионного суда 117, 244 [265f.]), Конституционный суд определил, что сама публикация официального секрета журналистом является недостаточной причиной для оправдания подозрения, приводящего к расследованию и задержанию. Наоборот, необходимы конкретные факты, указывающие на то, что лицо, занимающее соответствующую должность, действительно планировало опубликовать секретную информацию, что затем могло считаться преступлением, предполагающим соучастие. Смотри «Проект закона о защите свободы печати» принт Бундестага 16/4539, 6 марта 2007. Смотри еще «Критика расследований против журналистов», Stern.de (3 августа 2007); доступно на www.stern.de/politik/deutschland/bnduntersuchungsausschuss-kritik-an-ermittlungen-gegen-journalisten-594417.html. Смотри также «Расследования против журналистов за нарушение секретности», faz.net (2 августа 2007); доступно на http://www.faz.net/aktuell/politik/inland/medien-ermittlungen-gegenjournalisten-wegen-geheimnisverrats-1459900.html.

62 Смотри Процедурные правила Бундестага, § 125; Wulf Damkowski, Der parlamentarische Untersuchungsausschuss: Ein Handbuch für Wissenschaft und Praxis [Парламентская комиссия для расследования: Руководство для теоретиков и практиков] (Frankfurt: Campus Verlag, 1987), $31 \mathrm{ff}$. 
По соображениям прозрачности, обычной процедурой является деклассифицирование многих частей информации до публикации в соответствии с параграфом 33 Акта о ПКР. Бундестаг и Федеральное правительство стараются не допустить непреднамеренного раскрытия классифицированных материалов. По этой причине в окончательном докладе не цитируются секретные документы. Вместо этого, доклад ссылается на пресс-релизы, которые описывают неосторожное обращение с секретными данными.

Парламентские фракции могут комментировать окончательный доклад. Такие констатации иногда могут содержать несколько сотен страниц. ${ }^{63}$ Хотя опубликование оппозиционных мнений несколько чуждо немецкой юридической традиции и является недавним заимствованием из англо-саксонской правовой практики, парламентские заявления, похоже, стали установленной частью процедуры парламентского расследования. Фракции могут иметь отличающиеся оценки и иногда даже в их описаниях фактов и обстоятельств. Как раньше было упомянуто, нет никаких положений, предполагающих участие исполнительной власти в разработке или при комментировании доклада ПКР.

Официально существование ПКР заканчивается принятием окончательного доклада для Бундестага. ${ }^{64}$ Председатель комиссии передает копию доклада Президенту Бундестага. Это может произойти одновременно с представлением доклада прессе. Фокус общественного внимания обычно приходится не на самый окончательный доклад. Просто из-за его объема широкая публика вряд ли будет его читать. В первую очередь доклад представляет интерес для экспертов-юристов, ученых в области общественных наук и будущих историков.

В глазах общественности эти процедуры завершают работы комиссии. В самом парламенте продолжается припоминание спорных вопросов, повторяются и отвергаются обвинения и заново переживаются эмоциональные моменты. Для ведомств из сферы безопасности и для органов правопорядка, ПКР означает, что будут сделаны выводы, которые могут привести к новым руководящим положениям для исправления недостатков. К примеру, некоторые административные процедуры, которые выглядели несложными и прямолинейными в 1980-х и 1990-х, были сделаны существенно более строгими в результате реакции на выводы ПКР.

\section{Может ли опыт Германии служить моделью?}

Предыдущий анализ показал, что есть напряжение между законодательными требованиями для обеспечения прозрачности и ограничениями исполнительных органов при предоставлении информации. Эта спорная ситуация существует на всех уровнях - от тривиального установления фактов до изощренной правовой интер-

63 Смотри «ПКР Кундуз»; «Констатации», $413 \mathrm{ff}$.

64 Это обычно происходит на последнем заседании Бундестага перед летними каникулами - т.е. приблизительной за три года до следующих выборов. Смотри, к примеру, «Первая ПКР парламента шестнадцатого созыва», 18 июня 2009; «Плутониевая ПКР», 28 мая 1998; «Коммерческая координация», 27 мая 1994; «ПКР Виза», 2 сентября 2005. 
претации Федеральным конституционным судом. В июне 2009 Федеральный конституционный суд рассмотрел баланс между призывом к «как можно большей» прозрачности и требованием обеспечить «настолько, насколько необходимо» защиту информации. В итоге преимущество было отдано прозрачности перед проблемами безопасности.

Реформистки настроенные группы в государствах, находящихся в состоянии перехода к демократии, могут воспринять это решение как поощрение требовать большей прозрачности и от их сектора безопасности. С точки зрения внешнего наблюдателя, глубина расследования, необходимое время и занятый персонал, как и связанные с этим правовые и политические аспекты могут показаться очень сложными. Система парламентских расследований в Германии, с ее пристрастием к деталям, подходит под тевтонский стереотип. Однако, постоянное подвергание сомнению и постоянное корректирование работы ведомств в сфере безопасности было фундаментальным положением в послевоенной Германии. Система парламентских расследований в Германии является результатом истории, к которой другим государствам не нужно обращаться с таким упорством.

Юридическая сложность понятна, учитывая запросы по внешней политике и политике безопасности, которые направляют в Федеральный конституционный суд разные правительственные и оппозиционные партийные коалиции. В Германии не считаться с решениями Федерального конституционного суда немыслимо. Поэтому законодательная и исполнительная власть стараются интегрировать решения Федерального конституционного суда в свои административные процедуры.

Нужно сказать, что ПКР является не только форумом для обсуждения противоположных юридических мнений и интересов. В Германии они являются еще и форумом для обсуждения таких фундаментальных политических проблем, как борьба против терроризма, направление немецких солдат за границу и позиция Германии в разных альянсах.

В государствах, находящихся в состоянии перехода, и в постконфликтных государствах есть один вопрос, который вызывает определенный скептицизм: раскрытие классифицированной информации. Иногда публикуются оперативные подробности - информация, которая в большинстве государств была бы секретной. Такая прозрачность, вероятно, не будет иметь поддержки в государствах, в которых службы безопасности были опорой власти в течение десятилетий. В диалогах по реформе в секторе безопасности (РСБ) обычно иностранные эксперты говорят, что прозрачность желательна, но не до той степени, в которой она осуществлялась в центрально-европейском контексте. Множество государств, находящихся в состоянии реформирования своих секторов безопасности, часто еще борются с неразрешенными внутренними и внешними конфликтами. Часто подчеркивается, что сложные ситуации в сфере безопасности не являются подходящей средой для прозрачности в службах безопасности. Иными словами, хрупкая среда безопасности не является поводом постоянно оправдывать действия в секторе безопасности. 
Прозрачность ведомств безопасности рассматривается как нечто, что могут себе позволить экономически процветающие государства, находящиеся в геостратегической зоне безопасности Европейского Союза. Такие заявления надо воспринимать на полном серьезе при обсуждениях по РСБ. Отделение структур безопасности от структур законодательной, исполнительной и судебной власти может быть трудным, но найти правильные сдержки и балансы очень важно. Любые серьезные усилия в этом направлении следует поощрять. При инициировании реформ следует учитывать, что каждый конфликт имеет свои собственные условия: конфликты на Южном Кавказе не разрешены, на Балканах в конфликтах преобладает риторика, и у Ближнего Востока есть своя собственная традиционная динамика. Доброжелательный совет, данный на расстоянии в условиях традиционной безопасности, может быть воспринят представителями исполнительной власти и реформаторами как проявление западного или евроцентрического нахальства.

Как минимум, надо предлагать, чтобы РСБ-проекты на своих начальных этапах были направлены на установление системы функционирующего контроля на уровне министерств. Учреждение постоянных органов контроля с доступом к данным можно осуществить потом. Установление системы ПКР, сравнимой с немецкими стандартами, было бы завершением процесса реформ.

Независимо от того, какие формы контроля и надзора за ведомствами безопасности (в том числе и разведывательных служб) будут создаваться, надо понимать, что парламентский надзор предполагает сложную и учитывающую все детали систему парламентского расследования. Она может служить матрицей для идентификации областей, где потенциально существуют недостатки. Следуя этому пути, законодательной и исполнительной власти надо будет постоянно и многосторонне балансировать прозрачность и защиту государственных интересов. В пользу реформ может говорить тот факт, что при парламентской системе контроля у исполнительной власти есть законные средства и возможности избегать ненужных раскрытий. Комиссии для парламентского расследования следует рассматривать как возможность реагировать на критику общества, устранять причины для такой критики и раскрыть обществу сложность противоречивого процесса принятия решений. Если такой подход ведет к установлению недостатков в секторе безопасности и используется для осуществления институциональных и персональных изменений, его надо рассматривать как шаг вперед в РСБ и, соответственно, в осуществлении хорошего управления. 


\section{Литература}

Achterberg/Schulte Kommentar zum Grundgesetz [Commentary on the German Basic Law]. 4th ed. Vol. 2. Munich: Vahlen, 2000.

Administrative Regulation of Classified Documents., 2013.

Assessment Report of the Parliamentary Committee of Inquiry: Elbe Philharmonic Hall, Citizens of the Free and Hanseatic City of Hamburg., 2011.

BND-Ausschuss. Die Zeit online, 2006.

Committee Finds that Chaos Reigns in the Security Services., 2013.

Committees of Inquiry Act of the Berlin Chamber of Deputies., 2013.

Committees of Inquiry Act., 2013.

Constitutional Court of Saxony., 2008.

Criticizing Investigations Against Journalists. Stern.de, 2007.

Damkowski, Wulf. Der parlamentarische Untersuchungsausschuss: Ein Handbuch für Wissenschaft und Praxis [The Parliamentary Investigation Committee: A Manual For Academics and Practitioners]. Frankfurt: Campus Verlag, 1987.

Decision by the 2nd COI (Visa CoI) In Bundestag print., 2005.

Decisions by the Bavarian Constitutional Court ., 2013.

Decisions by the Federal Constitutional Court., 2013.

Die parlamentarische Kontrolle der Nachrichtendienste [Parliamentary Control of the Intelligence Services]. Neue Zeitschrift für Verwaltungsrecht, 2000.

Draft Law on the Protection of the Freedom of the Press In Bundestag print., 2007.

First COI of the Sixteenth Election Period In Bundestag print., 2009.

Hecker, Jan. Anmerkung zum BVerfG-Beschluss vom 17.06.2009 [Comment on the

Decision of the Federal Constitutional Court of 17 June 2009] In Deutsches Verwaltungsblatt. Vol. 19., 2009.

Hömig, Dieter. Grundgesetz für die Bundesrepublik Deutschland-Taschenkommentar. 7th ed., 2013.

Investigation of the role of the Bundestag and, in particular, of the Federal Ministry of Finance in the proceedings concerning the Hypo Real Estate (Hypo-Real-Estate IC) In Bundestag print., 2009.

Investigations Against Journalists for Breach of Secrecy. faz.net, 2007. 
Kunduz COI In Bundestag print., 2011.

Plutonium COI In Bundestag print., 2008.

Priest, Dana. "CIA Holds Terror Suspects in Secret Prisons." Washington Post (2005).

Recommended Decision and Report of the Committee for Transport, Construction and Urban Development. Stuttgart: BT-D print, 2011.

Reinhard Bergmann in Grundgesetz für die Bundesrepublik DeutschlandTaschenkommentar [Basic Law for the Federal Republic of Germany-Pocket Commentary]. 7th ed. Berlin: Nomos, 2003.

Reply by the Federal Government: Procurement of weapons from the East by the Federal Intelligence Service and transit shipment to friendly states In Bundestag print.

Request for Setting up a COI In Bundestag print., 2012.

Request to Set up a Committee of Inquiry In Bundestag print., 2012.

Rules of Procedure of the Bundestag., 2013.

Schreiner, Hermann. "Die Berliner Stunde-Funktionsweise und Erfahrungen: Zur Redeordnung des Deutschen Bundestages [The Berlin Hour-How it works: The Rules for Speakers in the German Bundestag]." Zeitschrift für Parlamentsfragen 36, no. 6 (2005): 573-88.

The Green Party, the Liberals and the Left Party Decide to Set up a COI to Inquire into the BND Scandal. Der Spiegel online, 2006.

Towards Effective Democratic Oversight of Intelligence Services: Lessons Learned from Comparing National Practices. Connections: The Quarterly Journal 3, no. 4 (2004): 1-12.

van Buuren, Jelle. Secret Truth: The EU Joint Situation Centre. Amsterdam: Eurowatch, 2009.

Visa COI In Bundestag print., 2005.

We Literally Know Nothing. Süddeutsche Zeitung, 2012. 